\title{
PROCESSING INSTRUCTION AND ENGLISH CAUSATIVES
}

\author{
Zehra Karacaer
}

\begin{abstract}
This study attempts to examine possible effects of two types of instruction: processing (PI) and traditional (TI) in learning of English causatives by Turkish learners and to see whether possible positive effects are retained well over time by PI and TI groups. Results indicated that both groups resulted in some kind of knowledge gain and had a positive effect on how learners interpreted and produced the English causatives. The effects of the treatments were retained over time in the interpretation of causatives, whereas both the PI and TI groups failed to show the same performance in the production of causatives.
\end{abstract}

Keywords: Processing Instruction, Traditional Instruction, Input Processing, First Noun Strategy, Causatives

\section{SÜREC ODAKLI DILL ÖĞRETIMİ VE İNGILIIZCEDEKİ ETTIRGEN ÇATI}

\begin{abstract}
$\ddot{O} z e t$
Bu çalışma, süreç odaklı dil öğretimi ve geleneksel dil öğretiminin Türk ögrencilerin İngilizcedeki ettirgen çatıyı öğrenmelerindeki olası etkilerini karşılaştırmayı; bu iki öğretim yönteminin olası olumlu etkilerini ve bu ögrenmenin uzun süreli bellekte kalıcı olup olmadı̆̆ını incelemeyi amaçlamıştır. Bulgular, hem süreç odakl grubun hem de geleneksel grubun bir tür kazanım elde ettiğini; Ingilizcedeki ettirgen çatıyı yorumlama ve üretme konusunda olumlu bir etkiye sahip olduğunu göstermiştir. Ettirgen çatıy yorumlama konusunda uygulamaların etkileri zaman içinde kalıcı olurken, ettirgen çatıyı üretme konusunda hem süreç odaklı grup hem de geleneksel grup aynı başarıy gösterememiştir.

Anahtar Sözcükler: Süreç Odaklı Dil Öğretimi, Geleneksel Dil Öğretimi, Girdi İslemleme, Ilk Ad Stratejisi, Ettirgen Çatı
\end{abstract}




\section{INTRODUCTION}

In the 1960s, studies in second language acquisition (SLA) sought to investigate what kind of grammar instruction most facilitated SLA (Sherer \& Werheimer, 1964, cited in Cadierno, 1995). Second language research from the $70 \mathrm{~s}$ to the present has aimed at investigating whether grammar instruction helps SLA. Here, grammar instruction means 'teacher's attempt to intervene directly in the process of interlanguage construction by providing samples of specific features of learning' (Cadierno, 1995:179). Today, the role of grammar instruction is widely accepted (For a review of research on second language instruction, see Long, 1983 and Norris \& Ortega, 2000).

Even though the role of explicit grammar instruction is considered to be important, observations show that still there are less proficiency gains (learners' use of the selected grammatical structures accurately) in the learning of certain structures such as English causatives.

For example, Montrul (2001) investigated whether Spanish- and Turkish- speaking learners of English discover the semantic and syntactic constraints on the causative / inchoative (e.g. 'The door opened.') alternation in the absence of overt morphological clues. She selected lexical causatives (e.g. open, cut, sink, melt,etc.) and the periphrastic causative make. The results of a Picture Judgment Task showed that L2 learners find these two types of causatives. However, the Turkish group, at a lower proficiency level than the Spanish group, accepted transitivity errors with unaccusative, unergative and non-alternating transitive verbs. The Turkish learners were very inaccurate with the periphrastic make construction while the Spanish learners were accurate, with a few exceptions.

Regarding the less proficiency gains, students attending Eskişehir Anadolu University, Turkey can be a good example. These students are required to complete one-year preparatory program before starting their own school and are assigned to different language levels based on the score they get from the Michigan Placement Test. In this intensive preparatory program, students take six lessons: core course, grammar, writing, reading, speaking, and listening. A pedagogical grammar, represented in foreign language textbooks (Tonkyn, 1994; cited in Tschirner, 1996), is taught in a traditional fashion. In other words, rules are provided explicitly and then students are required to produce the structures taught. The activities are composed of mechanical ones such as fill-in-the blanks, multiple choice, circle the correct answer, which require students to work individually most of the time. Observations show that even intermediate level students make errors in most grammatical structures.

As in Montrul's study, a pilot test administered by the researcher at the end of the 20002001 Spring Term showed that English causative constructions were problematic for Turkish 
learners of English at intermediate level even though they received plenty of exposure to English. We can give the following explanations for the source of this problem: (1) developmental factors affect learners' learning of the English causatives; (2) the methodology of English causatives requires some modernization; that is, an alternative to the output-based traditional grammar instruction (Collentine, 1998: 576); (3) it is unlikely to reflect psycholinguistic processes; and (4) learners are not ready to learn the target structures (Heilenman, 1995) (See Pienemann, 1989 for teachability and readiness issues).

\section{BACKGROUND}

Depending on the goal of instruction, grammar instruction has had a variety of forms. In grammar-translation approaches, the goal of foreign language learning was to read the great works of literature in that language. Grammar-translation dominated in language teaching until the emergence of Audio-lingual Method, which was supported by American structural linguistics and the theory of behaviorism. In audio-lingual method, the grammatical system was viewed as a set of habits to be internalized through practice and reinforcement. Without knowing the rules, learners had to correctly repeat, transform, and perform other manipulations on sentences orally as a necessary first step toward communicative ability with the language.

When behaviorism and structural linguistics lost influence, cognitive code learning emerged. Cognitive code theory claimed that learners must know what they are learning and have some conscious mental representation of it before practice.

Garrett (1986) suggests a psychological processing approach to the teaching and learning of grammar. Following Garrett (1986) and VanPatten and Cadierno (1993), within the last few years, studies have been conducted on the relative effects of two different types of explicit grammar instruction (EGI): processing instruction (PI) focusing on the learners' processing strategies followed by input-based practice and traditional instruction (TI) focusing on traditional grammar explanation followed by output-based practice.

VanPatten (1990, cited in Benati, 2001) has argued that PI, which helps learners process information via comprehension practice might be more effective than traditional instruction which requires learners to produce language too prematurely.

The PI approach maintains that SLA occurs through a series of processes. The first of these processes in VanPatten's model of acquisition is called 'input processing', which occurs as learners derive intake from input. PI aims to improve the quality of the input received by learners so that the amount of input becoming intake will increase. This is done by giving learners the opportunity to process grammatical forms in the input and make formmeaning connections (see a sample presentation in Appendix A). 
In order to see the connection between input processing and instruction, we should illustrate the TI in foreign language teaching. TI involves explanation and output practice of a grammatical point and focuses on the manipulation of learner output to affect change in the developing system. PI attempts to change the strategies and mechanisms used by language learners when processing L2 input, whereas TI involves presenting learners with explanations regarding the form and then giving them practice in how to make sentences with the relevant grammar point.

One processing strategy is the first noun strategy - the tendency to assign the role of agent (or subject) to the first noun (phrase) appearing in the sentence (For other processing strategies, see VanPatten, 1996). In their notable study, VanPatten and Cadierno (1993) attempted to change the learners' reliance upon the first-noun strategy when processing input containing Spanish clitic object pronouns. They compared the effects of PI and TI on learners' ability to comprehend and produce sentences containing Spanish clitic object pronouns. The results showed that the PI group did significantly better than the TI group in comprehension tasks and performed just as well as the TI group on production tasks.

Following VanPatten \& Cadierno (1993), several PI studies have been conducted in order to compare the relative effects of mostly PI and TI (e.g. Cadierno, 1995; Cheng, 1995; DeKeyser \& Sokalski, 1996; Tanaka, 1996; Salaberry, 1997, cited in Allen, 2000; Collentine, 1998; Nagata, 1998; Allen, 2000; Benati, 2001; Cantürk, 2001; Farley, 2001; and VanPatten \& Wong, 2004). These studies except DeKeyser\& Sokalski, Salaberry, Collentine, Allen, Cantürk found similar results to the original VanPatten \& Cadierno (1993) study. DeKeyser \& Sokalski (1996), Salaberry (1997, cited in Allen, 2000), Collentine (1998), Allen (2000), and Cantürk (2001) found no significant differences between PI and TI groups on either the comprehension or the production tasks.

Two of these studies, Allen (2000) and VanPatten \& Wong (2004), are particularly relevant to the present study because both of them compare the effects of PI versus TI on the French causative, which involves the first noun strategy.

Allen (2000) tried to replicate the VanPatten \& Cadierno (1993) study conceptually as suggested by Polio \& Gass (1997). She investigated the relative effect of PI and TI on the acquisition of the French causative and found that PI was as effective as TI enabling learners to interpret the French causative and that traditional instruction is more effective in enabling learners to produce the French causative.

VanPatten \& Wong (2004) replicated Allen's study and found different results from her study but similar results to the original VanPatten \& Cadierno study (1993). That is, on the interpretation task, PI group was superior to TI group, which was superior to the control group. On the production task, there was no significant difference between PI and TI groups. Both groups were superior to the control group. The gains did not hold over time. 
Even though DeKeyser et al (2002) questioned the explanatory adequacy of the model of IP, the validity of the limited-capacity, single-resource model of attention, the research on PI showed that PI can be a good alternative to grammar instruction (For VanPatten's response to DeKeyser et al. (2002), see VanPatten, 2002b).

The present study is an attempt to investigate the possible effects of two different types of grammar instruction: processing and traditional in learning of English causatives by Turkish learners and to see whether the possible positive effects are retained well over time by PI and TI groups. The study compares PI with TI on Turkish learners' ability to comprehend and produce sentences containing periphrastic causatives have, make, and get, in which the subject of the caused event becomes the object of the causative verb, regardless of whether the caused event is transitive or intransitive. The reason why we had chosen causatives in English as target structures was that they were the most appropriate structures to analyze the first noun strategy. The Passive voice could have been selected as target structures for this study, but the passive voice is more salient to Turkish learners of English than causative constructions. That is, we can find the passive voice in almost every grammar book, so learners are familiar with those structures. However, English causatives are not found in grammar books in detail. Moreover, the pilot test showed that periphrastic causatives have, make, and get were problematic for Turkish learners of English and they used the first noun strategy. An analysis of passive causatives have and get (e.g. I had/got my car serviced.) is beyond the scope of the present study.

The study addressed the following research questions:

1. Will there be any statistical differences among the interpretation of the English causatives by the following groups of learners:

a) those who receive processing instruction,

b) those who receive traditional instruction, and

c) those who receive no instruction on the English causatives?

2. Will there be any statistical differences among the production of the English causatives by the following groups of learners:

a) those who receive processing instruction,

b) those who receive traditional instruction, and

c) those who receive no instruction on the English causatives?

3. Would the possible positive effects for instruction on the interpretation task be retained equally well over time by the two instructional groups (processing and traditional)? 
4. Would the possible positive effects for instruction on the production task be retained equally well over time by the two instructional groups (processing and traditional)?

\section{METHOD}

\section{Subjects}

The subjects were Turkish students of English attending preparatory program at the School of Foreign Languages at Eskişehir Anadolu University, Turkey in the Fall Term of the 2002-2003 academic year. Their language level was intermediate and determined by the Michigan Placement Test.

Following Norris \& Ortega's (2000) suggestion of true control groups in experimental and quasi-experimental study designs, a control group was added to the research design. For Norris \& Ortega, the function of a true control group is to understand whether the possible gains in the PI and TI groups' scores after instruction occurred because of only the treatment or the other factors such as maturation due to exposure to English in the two treatment groups' regular classes, practice on the pretest, and so on. In this way, one may 'identify better the amount of observed effects attributable to instructional treatments' (Ibid: 497). The seven classes were randomly assigned to one of the three instructional groups: the processing instruction group (two classes), the traditional instruction group(two classes), and the control group (three classes), as in VanPatten \& Cadierno (1993) and VanPatten \& Wong (2004). While PI and TI groups were under treatment, the control group received no instruction on English causatives and continued their regular classes in Prep. Program.

A pretest was given to 171 subjects ( 74 females and 97 males). As estimated earlier, the number of subjects in each group, especially in the control group, decreased due to the official holidays in Turkey. The final data pool was composed of the subjects who were present for the pretest, full treatment, posttest, and follow-up test. The cut-off point on the pretest was determined as $60 \%$ in order to investigate the level of improvement. The final $n$ sizes were as follows: Processing $\mathrm{n}=41$ (17 females and 24 males), Traditional $\mathrm{n}=39$ (14 females and 25 males), and Control $\mathrm{n}=40$ (18 females and 22 males). The number of females and males was given to show that the population of the subjects was not composed of only females or males. Note that the gender is not one of the variables in this study. The age range was from 17 to 22 .

\section{Instruments}

\section{Instructional Packets}

Separate instructional packets for the processing and traditional groups were developed and balanced in terms of (a) vocabulary, (b) number of activities, and (c) practice time. As in 
VanPatten \& Cadierno (1993), the first page of both packets contained explicit grammar instruction about the causative constructions (see Appendix A). The processing group would also receive information about the word order problem that learners of English are confronted with while interpreting sentences that contain the causative constructions. The traditional group was not given this information since it was not the part of traditional approaches to grammar instruction and treating processing problems during explicit instruction was not common in traditional approaches.

In the processing packet, the activities were composed of structured input activities that consisted of both referential (Activities A through E) and affective (Activities $\mathrm{F}$ through J) activities. Referential activities are those meaning-based activities with right or wrong answers; for example, students hear a sentence and match it to one of the two pictures. Affective activities are those in which students react to a statement or sentence by indicating whether or not it is true for them, who in their family does that, and so on (For the examples of referential and affective activities, see Appendix B).

As in the VanPatten \& Cadierno study, activities in the traditional packet followed the pattern of moving from mechanical (Activities A through E), to meaningful (Activities F through $\mathrm{G}$ ) and to communicative practice (Activities H through J) (see Appendix B).

The differences between the activities in the processing and traditional group can be summarized as follows: (a) structured input activities in the processing group make students attend to both meaning and form to successfully complete the activities but they never required students to produce the target structures; (b) activities in the traditional packet make students produce the target structures; the initial activities do not require students to attend to meaning to successfully complete the activities.

\section{Assessment Tasks}

In order to assess the effects of instruction, two versions of the assessment task as the pretest and posttest/follow-up test were developed by the researcher. Each test consisted of two parts: an interpretation task and a production task. These versions differed in terms of the order of questions and the names of subjects and objects in each sentence, but the content stayed the same.

As an interpretation task, a listening-based, three-option task was constructed. The students listened to the ten sentences including causative make, get, and have and noncausative make, get, and have and selected the meaning of each sentence. Ten items contained causative constructions and the remaining six were distracter items. After the pilot studies, several items in the interpretation task were revised. 
In the production task, students were asked to write a sentence describing the situation in each picture. The first part of each sentence was made available for them as in the pilot studies, but there was a difference. Two verbs were given and the students had to choose the right verb and complete the rest of the sentence. After the pilot studies, it was thought that test familiarity might have made the traditional group more advantageous. In order to change the production task, it was decided to give two verbs. In this way, students would not give multiple possible answers and the researcher would be able to see whether students would select the right verb according to the meaning differences between make, get, and have. Five of these items were target items that required students to use the causative constructions. Five remaining items were distracter items that required students to use reported speech. Distracter items were used in order to see if students actually learned something from instruction or if they applied a test-taking strategy; that is, they made all sentences causative constructions because that was what they had learned.

In order to measure the test's content validity, three experts in the dissertation committee were asked for feedback three times during one and a half years. Based on their comments on the test, some changes were made on the test throughout the study.

Their feedback on the second version of the test was considered to avoid possible factors affecting the subjects' scores in the tests. Thus, the second version of the post/follow-up test used in Pilot Study 2 was totally changed since its content was different from the pretest. It was decided that the names of subjects and objects should be changed, but the content should remain the same.

Their feedback on the production part of the test was seen valuable. The committee members thought that the TI group's superior performance in the production task in Pilot Studies 1 and 2 was due to the task familiarity; that is why, this part should be changed to a certain extent. In order to prevent such interfering factors that might affect the results on the production task, the necessary changes were made.

In this study, the reliability of the test used in pilot studies was estimated with split half method and the reliability coefficient of half of the test was computed to be 0.72 . The internal reliability coefficient of the total test given was calculated as 0.83 .

Since some changes were made from Pilot Study 1 to the present study, the reliability coefficient of the test employed in the present study was calculated. The reliability coefficient of the half test was 0.79 and the reliability coefficient of the total test was calculated as 0.88. For Darren \& Mallery (1995: 226), this means that the test was reliable enough. As a result, we can say that the test was valid and reliable and it was appropriate for this study. 


\section{Procedures}

\section{Data Collection}

In order to control teacher variables, the researcher delivered the explicit instruction and practice activities and administered the pretest, the posttest, and the follow-up test. Otherwise, there would be differences in terms of teaching style. Following VanPatten \& Cadierno (1993) and Allen (2000), all instruction took place in the students' regular classrooms during their regularly scheduled class times in the 2002-2003 Fall Term. The researcher was the teacher of the two classes. The teachers of five classes were removed and the researcher gave the explicit instruction, practice activities, the pretest, the posttest, and the follow-up test. In the pilot studies, it was observed that administering the instruction and posttest one week after the pretest caused students to remember the test items easily. Therefore, two weeks after the pretest, instruction and posttest were given. The administration of the instructional treatment and the posttest spanned two 50-minute class periods. The instructional treatment was not a rush; there were ten activities for each instructional group.

Immediately after the treatment ( 80 minutes), the posttest was given. In order to see whether or not the proficiency gains from instruction remained stable, the same posttest was given as the follow-up test. Five weeks after the posttest, the follow-up test was administered since prep. students were placed in different groups in the second semester. As a result, it was difficult to find the same students in the same classes. The researcher audio-taped the lessons that she gave in the processing and traditional groups in order to remember the stages of each instruction. All packets were picked up at the end of the treatments. None of the groups was assigned homework during the treatment and during the intervals between the posttest and follow-up test, no review of the English causatives was provided.

\section{Scoring Procedure}

Only target items were scored. The interpretation task was worth 10 points. One point was assigned for each correct response; incorrect responses received a score of zero. The production task was worth 10 points; 2 points were awarded for each of the five sentences students had written correctly. Half point in each sentence was assigned for each of the four criteria: (a) the correct infinitive form of the verb; (b) the inclusion and correct position of the object; (c) the correct infinitive form of the verb; and (d) the rest of the sentence. Half point in each sentence was not assigned for each of the following criteria: (a) the wrong choice of the causative verb; (b) the wrong choice of the second verb; (c) no object; (d) the wrong position of the object; (e) infinitive with to instead of bare infinitive; (f) bare infinitive instead of infinitive with to; (g) past participle form of the verb; (h) causative verb + object + verb + nothing; (I) gerund or preposition + gerund instead of bare infinitive or 
infinitive with $t o$; (j) to + object; and (k) the wrong choice of the object. The decision to assign 2 points per sentence was made in order to reveal intermediate effects of instruction (as in VanPatten \& Cadierno, 1993).

In order to achieve inter-rater reliability of the production (Part B) section of the pretest, posttest, and follow-up test, three raters scored the production task in each test. One of the raters was the researcher. The others were two English teachers who taught at the School of Foreign Languages. The raters were provided with a detailed key. For the three tests, coefficient alpha was computed for each test with the help of SPSS 11 (Statistical Packet for the Social Sciences) software. Coefficient alpha was ,9960 for the pretest; ,9941 for the posttest, and ,9930 for the follow-up test. These alpha results showed that the degree of similarity between three raters was quite high.

\section{Data Analysis}

At the end of the study, there were two sets of data: interpretation and production. For each subject who participated in the study, there were six types of data:

a) interpretation task scores obtained in the pretest;

b) production task scores obtained in the pretest;

c) interpretation task scores obtained in the posttest;

d) production task scores obtained in the posttest;

e) interpretation task scores obtained in the follow-up test;

f) production task scores obtained in the follow-up test.

In order to test whether there will be any statistical differences in the interpretation and production of English causatives have, make, and get by the three groups of subjects (PI, TI, and Control), the interpretation and production data were analyzed.

Raw scores from the pretest were submitted to a one-way analysis of variance (ANOVA) since there were three groups and one dependent variable (the interpretation task scores in the pretest or the production task scores in the pretest). Raw scores from the pretest, post/follow-up tests were submitted to a two- way ANOVA since there were three groups and two independent variables (instruction and time). When significant differences were found, a post hoc multiple comparison procedure, the Tukey HSD (honestly significant difference), was performed to establish the source of the differences (following Allen, 2000 and Benati, 2001). The SPSS 11 software was used to analyze the interpretation and production data.

\section{PILOT STUDIES}

After having obtained the results of the pilot test, the study was limited to only causative verbs make, have, and get and passive causatives have and get were excluded from the study. 
In order to experiment with the materials and tests, two pilot studies were conducted in the Fall and Spring Terms of the 2001-2002 academic year.

Subjects were Turkish students of English studying at the School of Foreign Languages at Eskişehir Anadolu University, Turkey. Their language level was determined by the Michigan Placement Test.

The results of Pilot Study 1 were as follows:

1. On the interpretation task, both the processing and the traditional groups made significant gains. The control group also made progress.

2. On the production task, both processing and traditional groups improved significantly, whereas the control group made no progress.

In Pilot Study 2, the subjects came from the same population as that described in Pilot Study 1 but were not the same subjects. Their language level was intermediate and they were assigned to three groups as in Pilot Study 1.

The results of Pilot Study 2 were as follows:

1. On the interpretation task, both the processing and traditional groups made significant gains and retained this performance across the posttest and follow-up test. The control group also made gains, but not as significant as the processing and traditional groups.

2. On the production task, both processing and traditional groups improved significantly, but only the processing and control groups retained this performance across the posttest and follow-up test.

\section{RESULTS}

Two one-way ANOVAs conducted on the pretest alone revealed no differences among the three groups before instruction $(\mathrm{F}=0,21 ; p=0,80$ for the interpretation task and $\mathrm{F}=1$, $18 ; p=0,31$ for the production task). This meant that any effects due to instruction were not related to prior knowledge or ability of any one group.

After all the tests had been applied, the results between pretest and posttest and between posttest and follow-up test were obtained. Table 1 illustrates the results of mean test scores and standard deviations for the PI, TI; and control groups. This table displays that for the interpretation data, both PI and TI groups improved from the pretest to posttest (PI: 3,008,46; TI: 3,23-7,17). The mean score decreased only slightly from the posttest to follow-up test for the PI group $(8,46-7,92)$, while the TI group's mean score remained stable $(7,17-$ $7,15)$. The control group slightly improved from the pretest to posttest $(3,05-4,27)$, but improved more from the posttest to follow-up test $(4,27-6,32)$. However, this group's mean score was still lower than the PI and TI groups'. 
For the production data in table 1, both PI and TI improved significantly greater than the control group from the pretest to posttest (PI: 2,57-8,49; TI: 2,78-8,41). The PI's mean score decreased slightly from the posttest to follow-up test $(8,49-7,67)$, whereas the TI's mean score decreased a great deal $(8,41-6,84)$. What was interesting here was that while both the PI and TI groups' mean scores became lower, the control group's mean score increased a little $(3,96-5,29)$. Nevertheless, that score was still lower than the PI and TI's mean scores (PI: 7,67; TI: 6,84; C: 5,29).

Table 1 Means and Standard Deviations of three groups for Interpretation and Production Tasks

\begin{tabular}{|llllllll|}
\hline & \multicolumn{3}{c}{ Pretest } & \multicolumn{2}{c}{ Posttest } & \multicolumn{2}{c|}{ Follow-up Test } \\
Variables & $\mathrm{n}$ & Mean & SD & Mean & SD & Mean & SD \\
\hline Interpretation & $\mathrm{a}$ & & & & & & \\
\hline PI & 41 & 3,00 & 1,70 & 8,46 & 2,00 & 7,92 & 2,61 \\
TI & 39 & 3,23 & 1,61 & 7,17 & 2,28 & 7,15 & 2,93 \\
C & 40 & 3,05 & 1,66 & 4,27 & 2,69 & 6,32 & 2,42 \\
\hline Production & $\mathrm{b}$ & & & & & & \\
\hline PI & 41 & 2,57 & 2,31 & 8,49 & 1,27 & 7,67 & 1,65 \\
TI & 39 & 2,78 & 2,27 & 8,41 & 1,37 & 6,84 & 2,49 \\
C & 40 & 3,31 & 2,11 & 3,96 & 2,35 & 5,29 & 2,16 \\
\hline
\end{tabular}

a range $=0-10 \mathrm{~b}$ range $=0-10$

\section{Interpretation Data}

In order to determine the possible effects of instruction on the way in which subjects interpret sentences containing the English causatives, raw scores of the interpretation pretest, posttest, and follow-up test were tabulated and a two-way analysis of variance (ANOVA) was performed. Instruction (PI, TI, and Control) was the between-subjects factor, whereas time (pretest, posttest, and follow-up test) was the within-subjects factor. The results of the ANOVA shown in Table 2 reveal a significant effect for instruction $(F=22,63, p=0,00)$ and a significant effect for time ( $F=114,06, p=0,00)$. This means that instruction had a significant effect on test performance. There was a significant interaction between instruction and time $(F=9,45, p=0,00)$. That is, the impact of instruction increased through time (before instruction and after instruction) and this increase caused a significant difference between the improvement of the three groups on the interpretation task. 
Table 2 Summary Table for ANOVA Analysis Using Interpretation Data obtained from three tests

df $\quad$ SS $\quad M S \quad$ F-Value Sig.

\begin{tabular}{llllll}
$\begin{array}{l}\text { Interpretation task } \\
\text { Source of variation }\end{array}$ & & & & & \\
Instruction & 2 & 231,30 & 115,65 & 22,63 &, $00 * *$ \\
Time & 2 & 1165,62 & 582,81 & 114,06 &, $00 * *$ \\
Time x instruction & 4 & 193,20 & 48,30 & 9,45 &, $00 * *$ \\
Residual (error) & 351 & 1793,36 & 5,10 & & \\
Total & 360 & 14792,00 & & & \\
\hline
\end{tabular}

$* p<, 05 ; * * p<, 01$

In order to determine which instruction caused the difference in the interpretation data, Post Hoc Tukey HSD tests were performed. According to the results of these tests, the effect for instruction was due to the following contrasts: PI was significantly better than Control ( $p$ $=0,00)$; TI was significantly better than Control $(\mathrm{p}=0,00)$; no significant difference between PI and TI was found $(\mathrm{p}=0,09)$.

After having found a significant effect for time in the interpretation data, Post Hoc Tukey HSD tests were performed in order to find out the source of the effect. According to the results of these tests, the effect for time was due to the posttest and follow-up test which were significantly different from the pretest $(\mathrm{p}=0,00)$. However, there was no significant difference between the posttest and the follow-up test ( $p=0,21$ ).

A visual representation of the gains and longer-term effects for the interpretation task across the pretest and follow-up test is shown in Figure 1.

Figure 1 Interaction Plot for Instruction and Time in the Interpretation Data

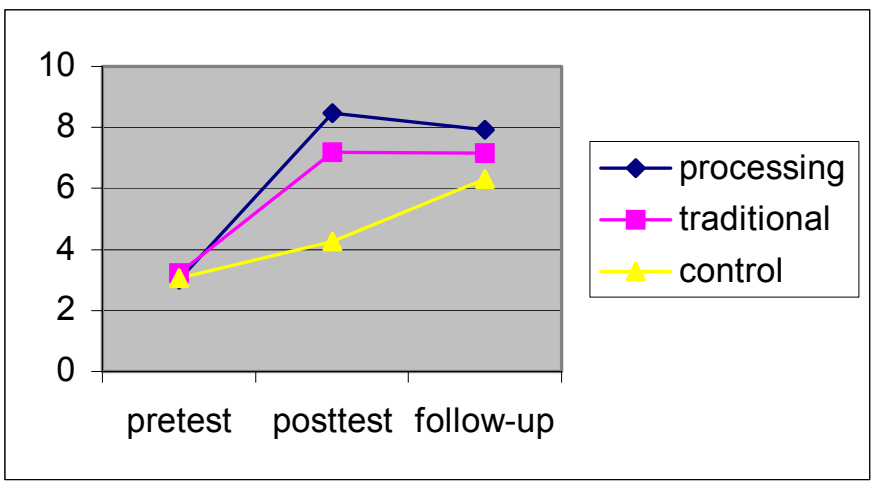




\section{Production Data}

In order to determine the possible effects of instruction on the way in which the subjects produce English causatives, raw scores of the production pretest, posttest, and follow-up test were tabulated and a two-way analysis of variance (ANOVA) was performed. The results shown in table 3 reveal a significant effect for time $(F=145,41, p=0,00)$. This means that instruction had a significant effect on test performance $(F=36,44, p=0,00)$. There was also a significant interaction between instruction and time $(F=21,67, p=0,00)$. That is, the impact of instruction increased through time (before instruction and after instruction) and this increase caused a significant difference between the improvement of the three groups on the production task.

Table 3 Summary Table for ANOVA Analysis Using Production Data obtained from three tests

df $\quad$ SS $\quad$ MS $\quad$ F-Value Sig.

Production task

Source of variation

\begin{tabular}{llllll} 
Instruction & 2 & 304,98 & 152,49 & 36,44 &, $00 * *$ \\
Time & 2 & 1216,96 & 608,48 & 145,41 &, $00 * *$ \\
Time x instruction & 4 & 362,71 & 90,67 & 21,67 &, $00 * *$ \\
Residual (error) & 351 & 1468,77 & 4,18 & & \\
Total & 360 & 14193,31 & & & \\
\hline
\end{tabular}

$* p<, 05 ; * * p<, 01$

In order to find out which instruction caused the difference in the production data, Post Hoc Tukey HSD tests were performed. According to the results of these tests, the effect for instruction was due to the following contrasts: PI was significantly better than control $(\mathrm{p}=$ $0,00)$; TI was significantly better than control $(p=0,00)$; there was no significant difference between PI and TI $(p=0,65)$.

To find out the source of the effect for time in the production data, Post Hoc Tukey HSD tests were performed. According to these tests, the effect for time was due to the posttest and follow-up test which were significantly different from the pretest $(p=0,00)$. However, there was no significant difference between the posttest and the follow-up test $(p=0,38)$.

A visual representation of the gains and longer-term effects for the production task across the pretest and follow-up test is shown in Figure 2. 
Figure 2 Interaction Plot for Instruction and Time in the Production Data

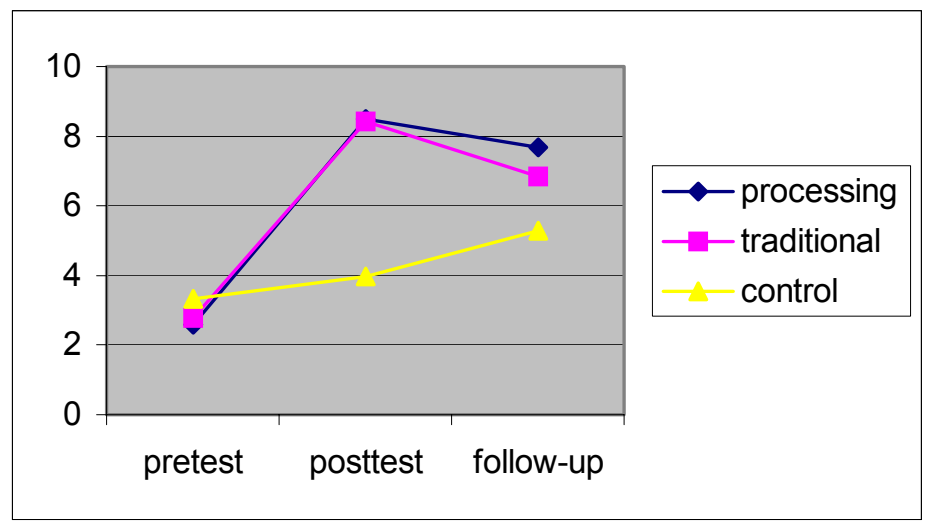

\section{DISCUSSION}

The results of the analysis of the interpretation data indicate that both the PI and TI groups resulted in some kind of knowledge gain due to the treatments. Both the PI and TI groups had a positive effect on how learners interpreted English causatives. The effects of both the PI and TI groups were retained over time. Consequently, the answers to the research question 1 about the statistical differences among the three groups on the interpretation task and the research question 3 about the retention of the possible positive effects for instruction on the interpretation task are positive. Both the PI and TI groups improved significantly greater than the control group. The improvement of the PI group on the interpretation task was greater than the TI and the control group. However, on the follow-up test, the control group improved, but their mean score was still lower than the PI's and TI's (PI: 7,92; TI: 7,15; C: 6,32). This kind of result might have happened due to the control group's maturation throughout the study and their practice on the tests (the pretest, posttest, and follow-up test).

The results of the analysis of the production data indicate that both the PI and TI groups resulted in some kind of knowledge gain due to the treatments. Both the PI and TI groups had a positive effect on how learners produced the English causatives. The answer to the second research question about the statistical differences among the three groups on the production task is positive. The effect of instruction for the PI group decreased slightly on the follow-up test, but the decrease on the TI group's scores on the follow-up test was bigger. However, the control group improved on the follow-up test due to maturation and practice on the tests, but their mean score was still lower than the PI's and TI's (PI: 7,67; TI: 6,84; C: $5,29)$. The answer to the fourth research question is no. The question asked whether the 
possible positive effects of instruction on the production task would be retained equally well over time by PI and TI groups. Both PI and TI groups could not continue the same improvement on the follow-up test. However, the drop in the TI group's scores was greater than the drop in the PI's scores. This may be due to memory limitations of both instructional groups. As a result, they may not have remembered the target structures they had been taught during the treatment.

When we compare the findings of the present study with the results found in Pilot Study 2 , we observe that on the interpretation task, the same results were found in the present study and Pilot Study 2. However, on the production task, there are differences between the results of the present study and of Pilot Study 2. In the present study, there was no significant difference between the PI and TI groups, whereas in Pilot Study 2, the TI group was better than the PI group. In Pilot Study 2, only the PI and control groups retained the proficiency gains across the posttest and follow-up test, while in the present study, both the PI and TI groups could not retain the gains and only the control group's scores were durable. Our assumption that the task familiarity of the TI group may have caused the greater performance on the production task was proved as right.

Regarding the increase in the control group's performance throughout the study, the effectiveness of the distracter items on both interpretation and production tasks was sought. In order to do that, the distracters were scored. The distracter items on the interpretation task (non-causative have, make, and get) were worth 6 points. The correct answer was awarded 1 point, whereas incorrect or no answer was awarded a point of zero. There were 6 distracter items. In the pretest, all subjects seemed to use the first noun strategy, with a score of 70 or over. In the posttest and follow-up test, the PI group outperformed the TI and Control groups. In the pretest, the control group got the highest mean score and their mean score increased across the pretest, posttest, and follow-up test $(4,57 ; 4,85$; and 4,90). Although the researcher placed the subjects into the three different groups in a random manner, the results of the pretest showed that the control group's listening comprehension was good enough from the beginning when compared to the PI and TI's. When we added their maturation, more exposure to English during this study, and practice on the test, their performance was likely to become better day by day. We saw that there was parallelism between two groups of items on the interpretation task when we compared the control group's performance in the distracters with the one in the target items.

For the distracter items on the production task, 0,5 point was awarded for each of the following criteria: a) Verb + Object + if / whether + the clause; b) Verb + Object + infinitive with $t o+$ the rest of the clause; or c) Verb + Object + Pronoun + Tense. Each item was worth 2 points. There were five distracter items (10 points). In the pretest, the control group outperformed the PI and TI groups. The TI group received the lowest mean. This means that 
the control group knew the reported speech better than the other two groups. Three groups performed better in the reported speech than in the causatives. In the posttest, it was observed that instructional groups (PI and TI) applied the causative rule (have / make / get + Object + (to) Verb) to the reported speech (e.g. The manager had Eric to have any experience). This means that the distracters were effective on the subjects who took the instruction. The rate of applying the causative rule to the reported speech was more in the TI group than the one in the PI group. Both the TI and control groups' scores dropped across the pretest and posttest, whereas the PI's score increased a little in the posttest. In the follow-up test, all groups' means increased since they were taught the reported speech in the grammar lesson before taking the follow-up test. When we added their maturation, more exposure to English during this study, and practice on the test, the control group's performance was likely to become better day by day. We observed that there was parallelism between two groups of items on the production task except for the little drop in the mean score of distracters in the posttest when we compared the control group's performance in the distracters with the one in the target items.

The distracter items were used to see if students actually learned something from instruction or if they applied a test-taking strategy; that is, they made all sentences causative constructions because that was what they had learned. In short, the distracter items on both interpretation and production tasks were effective enough. That is, they distracted some of the subjects in the instructional groups.

We should also consider the individual differences among these three groups. Firstly, we should take into account of the notion whether or not the subjects really wanted to participate in this study. Their intention to learn the structures should be considered. According to the results, the control group seems to really want to participate in this study. This may have caused the increase in their performance in both the distracter and target items on the interpretation and production tasks across the pretest, posttest, and follow-up test. Secondly, individual differences in working memory capacity for both input and output processing should be taken into account (VanPatten, 2003: 96). There may have been some students who had limited working memory in each group. These students may have had trouble with comprehension and production of English causatives. The findings of this study show that the control group seems to have more room in working memory. As a result, they remembered the items in both tests.

\section{Evaluation of the Results}

Regarding the results of the tests on the target structures (causative verbs have, make, and get), this study has shown the following about the effects of PI: 
- PI may convert some of the input data on English causatives to intake.

- PI has positive effects on the interpretation and production of English causatives by Turkish learners.

- PI is as effective as TI in learning of English causatives.

- The positive effects of PI are durable in the interpretation of English causatives by Turkish learners.

- The positive effects of PI are not durable in the production of English causatives by Turkish learners.

When we compare the results of this study with the results of the original VanPatten \& Cadierno study (1993), of Allen (2000), and of VanPatten \& Wong (2004), our results are similar to VanPatten \& Wong's on both interpretation and production tasks and similar to VanPatten \& Cadierno's only on the production task (see table 4).

Table 4 Summary Comparisons of Results from the Present Study with Results of Three Studies

\begin{tabular}{|c|c|c|c|c|}
\hline & $\begin{array}{c}\text { VanPatten } \\
\text { \& Cadierno } \\
\text { (1993) }\end{array}$ & Allen (2000) & $\begin{array}{c}\text { VanPatten } \\
\text { \& Wong (2004) }\end{array}$ & $\begin{array}{c}\text { The Present } \\
\text { Study }\end{array}$ \\
\hline Interpretation & & & & \\
\hline Posttest 1 & $\mathrm{PI}>\mathrm{TI}=$ Control & $\mathrm{TI}=\mathrm{PI}>$ Control & $\mathrm{PI}>\mathrm{TI}>$ Control & PI $>$ TI $>$ Control \\
\hline Posttest 2 & $\mathrm{PI}>\mathrm{TI}=$ Control & $\mathrm{TI}=\mathrm{PI}>$ Control & n.a. & $\mathrm{PI}=\mathrm{TI}>$ Control \\
\hline Posttest 3 & $\mathrm{PI}>\mathrm{TI}=$ Control & $\mathrm{TI}=\mathrm{PI}>$ Control & $\mathrm{PI}=\mathrm{TI}>$ Control & n.a. \\
\hline Production & & & & \\
\hline Posttest 1 & $\mathrm{PI}=\mathrm{TI}>$ Control & $\mathrm{TI}>\mathrm{PI}>$ Control & $\mathrm{PI}=\mathrm{TI}>$ Control & $\mathrm{PI}=\mathrm{TI}>$ Control \\
\hline Posttest 2 & $\mathrm{PI}=\mathrm{TI}>$ Control & $\mathrm{TI}=\mathrm{PI}>$ Control & n.a. & $\mathrm{PI}=\mathrm{TI}>$ Control \\
\hline Posttest 3 & $\mathrm{PI}=\mathrm{TI}>$ Control & $\mathrm{TI}>\mathrm{PI}>$ Control & $\mathrm{PI}=\mathrm{TI}>$ Control & n.a. \\
\hline
\end{tabular}

The results of the present study differ from Allen's. She found no difference between PI and TI on her interpretation task both immediately after treatment and later on a delayed posttest. As for the production task, she found an initial superior post-treatment performance for the TI that disappeared on the second posttest but then reasserted itself on the third posttest.

Allen shared her materials and assessment tasks which she used in her study with VanPatten and Wong. In this way, VanPatten and Wong interpreted her materials and 
assessment tasks in detail. Their opinions were made use of by the researcher in order to find out the origin of the differences in Allen's results.

According to VanPatten \& Wong (2004) and VanPatten (2002a), the difference in results might have occurred due to the materials- the nature of the instructional treatments in Allen's study as well as the nature of the assessment tasks used in her study. There seemed to be no clear distinction between PI and TI in Allen's study, whereas in the present study, VanPatten \& Cadierno's study, and VanPatten \& Wong's study, there was a clear distinction between PI and TI. Even though TI is defined as the move from mechanical to meaningful to communicative practice, Allen had the learners be engaged in processing input strings much in the same way they would if they were part of the PI group. Some of the items in Allen's study do not take into account event probability. Lexical semantics or event probability may help learners determine who does what (to whom). For example, when we look at the sentence The doctor made the patient stay in bed, we can easily interpret that the patient stayed in bed since in real life, doctors make patients stay in bed. In this way, they may respond correctly but not because they have learned or know anything about the structure in question.

Allen preferred the first-person sentence structure from the interpretation task to the production task. The third-person sentence structure was maintained across both tasks in the present study, as did VanPatten \& Cadierno and VanPatten \& Wong in their studies. Allen had the subjects write five sentences involving $X$ me font $Y$ as the base structure. In VanPatten \& Wong's study, the subjects had to discriminate between causative and noncausative faire in order to complete each sentence. In this way, VanPatten \& Wong could tell to what extent the subjects had truly learned something from the treatment. In the present study, we added non-causative make, have, and get on the interpretation task.

On the production task, we used introductory verbs in reported speech- say and ask since the context of the dialogues required reported speech as well as causative construction. While the instructional packets and assessment tasks were in preparation, we considered lexical semantics and event probability. As a result, we excluded the items containing lexical semantics and event probability from the instructional packets and assessment tasks.

Allen's study (2000) brings the issue of replication studies to question. We have to question whether or not Allen's study (2000) is a replication study. Her study at first seems to be a replication of the original VanPatten \& Cadierno study (1993); however, when we look at the materials, procedure and assessment used in that study, we can say that it may not be a true replication study. We should interpret her results with caution (for replication studies, see Polio \& Gass, 1997).

Even though VanPatten \& Wong (2004) conducted a PI study on a target structure in a different language (French) from the language chosen for this study, their results were the 
same as those of this study. This may have been due to selecting causativity. This denotes that both Turkish and English learners have a default strategy in causativity: the First Noun Strategy. Perhaps this strategy is universal, but this study did not aim at testing the question whether the first noun strategy is universal or not.

In conclusion, as Ellis (1999: 74) pointed out, PI may promote intake, but it failed to measure the communicative behavior. Furthermore, 'the implicit linguistic system develops slowly and requires much exposure to input' (VanPatten, 2003: 59). The present study spanned a few weeks; it was not a longitudinal study. However, we should accept the positive effects of PI in the interpretation and production of the English causatives by Turkish learners.

\section{PEDAGOGICAL IMPLICATIONS}

This study has indicated that explicit grammar instruction is beneficial in making the students in the PI and TI groups notice the English causatives since the control group did not improve as much as the instructional groups did.

With PI, the implication that grammar instruction should be meaning-based and tied to input (VanPatten, 2003: 110). Accuracy has been replaced by noticing things in the input. Noticing forms is important, since learners have difficulty with many of the grammatical features due to the following: a) these features may be non-salient or hard to notice; b) they may be infrequent in the input; and c) they may be unnecessary for successful (getting the gist type) comprehension (Heilenmann, 1995: 7). By using structured input activities, we can have our students notice grammatical features that are problematic.

PI seems to complement communicative language teaching, not to replace it (Ellis, 1993; VanPatten, 1996). This can be achieved by means of grammar lessons taught alongside communicative lessons that cater to spontaneous language use with a focus on meaning (Ellis, 1999: 74). PI requires a structural syllabus taught by means of structured input activities. For Ellis (1999: 75), this syllabus needs to be used in parallel with a communicative syllabus (e.g., a task-based syllabus) (see Skehan \& Foster (1997) for task type and task processing conditions).

With PI, the importance of attention to input has become evident. For Wong (2001: 2), 'the more we understand how learners attend to input, the better equipped we will be at helping them process language.'

For Gass (1988) and VanPatten (1994), (cited in Doughty \& Williams, 1998: 249), input that is not converted to intake is then lost and consequently is no longer available to any subsequent language acquisition processes. So, the important pedagogical issue is whether learners pay attention to form and how to get the attentional allocation increased, since the more one attends, the more learns. In order to increase attentional capacity, information may be presented in varying modalities. 
According to Wong (2001: 2-3), there are six necessary ingredients for successful adult language acquisition:

1. meaning- bearing comprehensible input

2. attention to input

3. means for making form-meaning connections

4. tasks that do not overload learners' processing capacity

5. opportunities for interaction and negotiation of meaning

6. a positively affective environment

We should bear in mind these ingredients and decide how to best incorporate these ingredients into our teaching. We can determine this according to the characteristics and needs of our students and of our curriculum (Ibid: 5-6).

When learners show no sign of comprehending a grammatical form, the focus should be on meaning. In IP, learners' false processing strategies are manipulated while metalinguistic information is kept to a minimum. If learners have some grasp of the meaning, more attention to form is possible. VanPatten suggests beginning with activities that require learners to process only input, as input shapes the necessary elements for the developing system. This helps learners to notice features of the input and to establish form-meaning connections. According to VanPatten, after these forms have been incorporated into the developing system, we can include output. The main purpose of this output is automatization and the development of fluency. (see VanPatten, 1996; VanPatten \& Cadierno, 1993)

A focus on IP does not necessarily show that there is no role for output. Input provides the data, IP makes certain data available for acquisition. Output can be facilitative in development of fluency and accuracy as well as of other aspects of language development (see also Gass, 1997; Swain, 1985, 1998).

The Comprehensible Output (CO) Hypothesis claims that under some conditions, output facilitates second language learning in ways that are different from, or enhance, those of input (Swain \& Lapkin, 1995). Krashen (1998) reviews the research and concludes that the claim of CO is hard to support.

When it comes to curriculum development, based on VanPatten's ideas on IP, Doughty \& Williams (1998) suggest a curriculum option regarding input processing:

A. Input $\rightarrow$ processing meaning

B. Input processing $\rightarrow$ intake of formal features

C. Output $\rightarrow$ fluency

This kind of option requires the combination of PI and communicative language teaching as suggested by Ellis (1999).

When we examine grammar textbooks, we can see, for example, causative constructions, mostly passive causatives, in one or two pages. In other words, some grammatical features 
are not included in textbooks in detail (For textbook issues, see Finneman, 1987 and Herschensohn, 1988).

Fuchs \& Bonner's 'Focus on Grammar' $(1995,2000)$ can be an exception for causative verbs have, make, and get, since causative verbs are explained in 10 pages. Fuchs \& Bonner first give structures in context and then try to make learners notice them. They integrate reading, listening, speaking, and writing. They start each unit with written and oral input. Later, they ask learners to access output through speaking and writing exercises. We can say that 'Focus on Grammar' can be a good example of joining input with output.

\section{SUGGESTIONS FOR FURTHER RESEARCH}

In this study, the effects of PI in learning of the English causatives were compared. Further research should be carried out to compare the effects of PI in the learning of different linguistic features in English.

The sample size of this study was small (120 subjects). Future studies may be conducted with a larger size.

The tasks on the pretest and the post/follow-up test had no communicative behavior; that is students were not asked to speak or to do pair-work. A communicative oral production task can be added to the test in a future study.

Larsen-Freeman (1997) claims that the idea that grammar has to do only with sentence level and sub-sentence level phenomena is a myth and that it would be a mistake to teach students grammar only at the sentence and sub-sentence levels. However, this study was at sentence level. Further studies may involve the English causatives at discourse level and explore that phenomenon.

In this study, only one processing strategy P3 (the first noun strategy) was investigated. Further studies may investigate other processing strategies in the VanPatten's Input Processing Model. For example, P1b (the lexical preference principle) may make predictions about a variety of grammatical features carrying semantic information encoded elsewhere in an utterance. P4 (the sentence location principle) can be utilized to examine forms in a language to decide to what extent they are acoustically non-salient (VanPatten, 2002a: 768).

Passive causatives were excluded from the study. In a future study, these causatives can be studied with causative verbs have, make and get.

Long-term effects of the two instructions (PI and TI) should be re-examined since the long-lasting effects of instruction in this study were measured only over a period of five weeks.

Input in this study (structured input) was controlled. In future studies, spontaneous input can be used by adding oral tasks.

Individual differences were not taken into account in this study. In a future study, learning styles and strategies of learners may be learned at the beginning. 


\section{CONCLUSION}

This study attempted to compare the effects of two types of instruction: PI and TI. The results showed that PI has positive effects on the interpretation and production of English causatives by Turkish learners; PI is as effective as TI in learning of English causatives; the positive effects of PI are durable in the interpretation of English causatives by Turkish learners; and the positive effects of PI are not durable in the production of English causatives by Turkish learners.

One of the reasons for causative constructions to be problematic can be the fact that they are less frequent in grammar books, thus they are non-salient to Turkish learners of English. Without underscoring the role of output in learning of grammatical features in English, first, we can use explicit information on causative constructions with making them notice their false processing strategies and then we can use 'structured input activities' including those problematic forms. After that, combining the structured syllabus with a task-based one, we can make them produce causatives in English and give them corrective feedback when necessary. In this way, we can have them notice their false processing strategies; change those strategies, and produce them in a communicative task.

This study showed that PI can be remedial for some non-salient problematic grammatical features in English. Language teachers and curriculum developers may include it in the curriculum with a communicative focus in order to solve their students' problems about those features.

\section{REFERENCES}

Allen, L.Q. 2000. Form-meaning Connections and the French Causative, Studies in Second Language Acquisition, 22: 69-84.

Azar, B.S. 1999. Understanding and Using English Grammar (3 ${ }^{\text {rd }}$ Edition). New York.: Longman.

Benati, A. 2001. A Comparative Study of the Effects of Processing Instruction and Output-Based Instruction on the acquisition of the Italian Future Tense, Language Teaching Research, 5/2: 95-127.

Cadierno, T. 1995. Formal Instruction from a Processing Perspective: An Investigation into the Spanish Past Tense, The Modern Language Journal, 79: 179-193.

Cantürk, B. 2001. Explicit Grammar Instruction: A Comparison of Comprehension-based and Production-based Instruction for EFL Learners, T.C. Anadolu Üniversitesi Yayınları: No.1276. Eskişehir: Yabancı Diller Yüksekokulu Yayınları: No. 01.

Collentine, J.G. 1998. Processing Instruction and the Subjunctive, Hispania, 81: 576- 587.

Darren, G. \& P. Mallery. 1995. SPSS / PC +: Step By Step: A Simple Guide and Reference 3/2”Dos Data Disk Enclosed. Belmont. Albany: Wadsworth Publishing Company: An International Thomson Publishing Company. 
DeKeyser, R. M. et al. 2002. What gets Processed in Processing Instruction? A Commentary on Bill VanPatten's "Processing Instruction: An Update”, Language Learning, 52 / 4: 805-823.

DeKeyser, R.M. \& K.J. Sokalski. 1996. The Differential Role of Comprehension and Production Practice, Language Learning, 46 / 4: 613-642.

Doughty, C. \& J. Williams. 1998. Pedagogical Choices in Focus on Form, in C. Doughty \& J. Williams (eds.) Focus on Form in Classroom Second Language Acquisition. pp.197261. Cambridge: Cambridge University Press.

Ellis, R. 1993. The Structural Syllabus and Second Language Acquisition, TESOL QUARTERLY, 27 : 91-113.

Ellis, R. 1999. Input-based Approaches to teaching Grammar: A Review of Classroom-Oriented Research, Annual Review of Applied Linguistics, 19: 64-80.

Farley, A. 2001. Authentic Processing Instruction and the Spanish Subjunctive, Hispania, 84: 289-299.

Finnemann, M. D. 1987. Liberating the Foreign Language Syllabus, The Modern Language Journal, 71: 36-43.

Fuchs, M. \& M. Bonner. 1995. Focus on Grammar: A High-Intermediate Course for Reference and Practice. London: Longman.

Fuchs, M. \& M. Bonner. 2000. Focus on Grammar: A High-Intermediate Course for Reference and Practice(2 ${ }^{\text {nd }}$ Edition). New York: Longman.

Garrett,N. 1986. The Problem with Grammar: What kind can the language learner use?, The Modern Language Journal, 70 / 2: 133-148.

Gass, S. M. 1997. Input, Interaction, and the Second Language Learner. Mahwah, New Jersey: Lawrence Erlbaum Associates.

Heilenman, K. 1995.Grammar, in V. Galloway \& C. Herron. (eds.) Research Within Reach II: Research-guided Responses to the concerns of Foreign Language Teachers. pp. 129148. Valdosta, G. A. SCOLT.

Herschensohn, J. 1988. Linguistic Accuracy of Textbook grammar, The Modern Language Journal, 72: 409-414.

Krashen, S. 1998. Comprehensible Output?, System, 26: 175-182.

Larsen-Freeman, D. 1997. Grammar and its Teaching : Challenging the Myths, ERIC Digest. pp. 1-4. Available online at http://www.ed.gov/databases/ERIC_Digests/Ed406829.html.

Long, M. 1983. Does Second Language Instruction make a Difference? A Review of Research, TESOL Quarterly, 17 / 3: 359-382.

Montrul, S. 2001. Causatives and Transitivity in L2 English, Language Learning, 51 / 1: 51-106. 
Nagata, N. 1998. Input vs. Output Practice in Educational Software for Second language Acquisition, Language Learning and Technology, $1 / 2$ : 23-40. Available online at http://polglot.cal.msu.edu/llt/vollnum2/article1/default.html.

Norris, J. M. \& L. Ortega. 2000. Effectiveness of L2 Instruction: A Research Synthesis and Quantitative Meta-Analysis, Language Learning, 50 / 3: 417-528.

Pienemann, M. 1989. Is language teachable? Psycholinguistic Experiments and Hypotheses, Applied Linguistics, 10: 52-79.

Polio, C. \& S. M. Gass. 1997. Replication and Reporting: A Commentary, Studies in Second Language Acquisition, 19: 499-508.

Skehan, P. \& P. Foster. 1997. Task type and task processing conditions as influences on foreign language performance, Language Teaching Research, 1/ 3: 185-211.

Swain, M. 1995. Communicative Competence: Some roles of comprehensible input And comprehensible output in its development, in S. Gass \& C. Madden (eds.) Input in Second Language Acquisition. pp. 235-253. Cambridge, M.A: Newbury House.

Swain, M. 1998. Focus on Form through Conscious reflection, in C. Doughty \& J. Williams (eds.) Focus on Form in Classroom Second Language Acquisition. pp.64-81. Cambridge: Cambridge University Press.

Tschirner, E. 1996. Scope and Sequence: Rethinking Beginning Foreign Language Instruction, The Modern Language Journal, 80: 1-14.

VanPatten, B. 1996. Input Processing and Grammar Instruction in Second Language Acquisition. Norwood, N.J: Ablex.

VanPatten, B. 2002a. Processing Instruction: An Update, Language Learning, 52 / 4: 755-803.

VanPatten, B. 2002b. Processing the Content of Input-Processing and Processing Instruction Research: A Response to DeKeyser, Salaberry, Robinson, And Harrington, Language Learning, 52 / 4: 825-831.

VanPatten, B. 2003. From Input to Output: A Teacher's Guide to Second Language Acquisition. Boston: McGraw Hill.

VanPatten, B. \& T. Cadierno. 1993. Explicit Instruction and Input Processing, Studies In Second Language Acquisition, 15: 225-259.

VanPatten, B. \& W. Wong. 2004. Processing Instruction and the French Causative: Another Replication, in B. VanPatten (ed.). Processing Instruction: Theory, Research, and Commentary. Pp. 97-118. Mahwah, New Jersey, London: Lawrence Erlbaum Associates.

Wong, W. 2001. Form-meaning Connections in Second Language Learning and Instruction in 2001 Combined 801 Teacher Training Workshop. Available online at http//www.flc.ohiostate.edu/flc_pages/801/wong.html. 


\section{APPENDIX A}

\section{EXPLICIT INFORMATION USED IN THE INSTRUCTIONAL PACKETS}

We often ask people to do things for us by telling them to do something.

Jack says, "Tina, would you mind cooking tomato soup?"

We can describe what is happening here as follows:

"Jack has Tina cook tomato soup."

This is called the causative construction since someone is causing something (a behavior) in someone else.

The causative verbs HAVE and MAKE are formed as in the following:

$\begin{array}{ccccc}\text { Subject } & \text { verb } & \text { object } & \text { base form } & \\ \text { They } & \text { (don't) make } & \text { us } & \text { do } & \text { homework. } \\ \text { have } & & & \end{array}$

The causative verb GET is formed:

$\begin{array}{ccccc}\text { Subject } & \text { verb } & \text { object } & \text { infinitive with to } & \\ \text { I } & \text { got } & \text { my brother } & \text { to carry } & \text { my suitcase. }\end{array}$

As seen above, the causative verbs have, make, get are located after the subject.

$\square$ We use causatives to emphasize the person who does the action.

Example 1: Mrs. Lee made her son clean his room.

Who cleaned Mrs. Lee's son's room? Mrs. Lee or her son?

Example 2: Jane had Sarah do the dishes.

Who did the dishes? Jane or Sarah?

Example 3: Ali got his barber to cut his hair short.

Who cut Ali's hair short? Ali or his barber?

MAKE, HAVE, and GET can be used to express the idea that ' $X$ ' causes ' $Y$ ' to do something. When they are used as causative verbs, their meanings are similar but not identical.

(a) I MADE my brother CARRY my suitcase.

Here, my brother had no choice. I insisted that he carry my suitcase. (insisting)

(b) I HAD my brother CARRY my suitcase.

Here, my brother carried my suitcase because I asked him to. (requesting)

(c) I GOT my brother TO CARRY my suitcase.

Here, I managed to persuade my brother to carry my suitcase. (persuading)

So, we can say that when we use the causative verb make, we insist that someone do something; when we use the causative verb have, we make a request, there is no insistence or using force; when we use the causative verb get, we persuade someone to do something.

(The following additional information is for PI only.) 
One of the problems the causative verbs (make, have, get) pose is in listening comprehension. Turkish learners often misinterpret what they hear due to the word order in causatives, so they tend to choose the first noun as the doer.

They hear: "John made Tom fix the tap."

They incorrectly think: "John fixed the tap for Tom."

But in fact it means "Tom fixed the tap for John."

In the following activities, we will practice hearing and interpreting the causative verbs make, have, and get.

(Adapted from VanPatten \& Wong, 2004)

\section{APPENDIX B}

\section{Example of Referential Activity in PI}

\section{ACTIVITY A:}

Listen to the sentences including causative constructions read by the teacher. Choose the correct interpretation of the sentence. Circle a or b. (The students are expected to answer the following as the teacher reads Activity A: Teacher's Script below. This will be carried out when the teacher reads the sentences given below.)

1. a) I washed the windows.

b) My son washed the windows.

2. a) Tim went to class for Tom.

b) Tom went to class for Tim.

3. a) Some kids in the neighborhood cleaned out Kostas's garage.

b) Kostas cleaned out his garage.

4. a) Richard redid her report.

b) Richard didn't redo her report.

5. a) Tom Sawyer painted the fence.

b) His friends painted the fence.

6. a) Cem took pictures of everyone.

b) We took pictures of everyone. 


\section{ACTIVITY A: Teacher's Script}

Read each sentence only ONCE. Review the answer after each question; do not wait until the end to review answers. Students do not repeat or otherwise produce the structure.

1. I made my son wash the windows before he could go outside to play.

2. Tom got his twin brother Tim to go to class for him.

3. Kostas got some kids in the neighborhood to clean out his garage.

4. Richard made Alice redo her report because he wasn't satisfied with it.

5. Tom Sawyer got his friends to paint the fence for him.

6. We had Cem take pictures of everyone who participated in our wedding.

\section{Example of Affective Activity in PI}

\section{ACTIVITY J:}

In groups of three, tick what your grammar teacher makes you do in the grammar lesson.

$\square$ Do fill-in-the-blank activities

$\square$ Do communicative activities

$\square$ Listen to a dialogue

$\square$ Work in groups

$\square$ Work in pairs

$\square$ Do multiple choice exercises

$\square$ Read a passage

$\square$ Do vocabulary exercises

$\square$ Work individually

$\square$ Do speaking activities

$\square$ Do listening activities

$\square$ Do reading activities

A person from one group stands up and presents that group's list of activities to the class. Does everyone agree with that list?

Now tick what your core course teacher makes you do in the core course lesson. 


\section{Example of Mechanical Activity for TI}

\section{ACTIVITY A:}

Complete the sentences with words in parentheses. (Azar, 1999)

1. I made my son (wash) the windows before he could go outside to play.

2. Tom had a bad headache yesterday, so he got his twin brother Tim (go) to class for him. The teacher didn't know the difference.

3. Kostas got some kids in the neighborhood (clean) out his garage

4. Richard made Alice (redo) her report because he wasn't satisfied with it.

5. Tom Sawyer was supposed to paint the fence, but he didn't want to do it. He was a clever boy. Somehow he got his friends (do) it for him.

6. We had Cem (take) pictures of everyone who participated in our wedding.

\section{Example of Communicative Activity for TI}

\section{ACTIVITY J:}

What does your grammar teacher make or have you do in the grammar lesson? Work in groups of five and make sentences about it. When you have finished it, compare your responses with other groups.

$\square$ Do fill-in-the-blank activities

$\square$ Do communicative activities

$\square$ Listen to a dialogue

Work in groups

Work in pairs

$\square$ Do multiple choice exercises

$\square$ Read a passage

$\square$ Do vocabulary exercises

$\square$ Work individually

$\square$ Do speaking activities

$\square$ Do listening activities

Do reading activities

Do your group and other groups have the same perception of the grammar lesson?

Now this time do the same thing for the core course lesson.

What does your core course teacher make or have you do in the core course lesson? Work in groups of five and make sentences about it. When you have finished it, compare your responses with other groups.

Do your group and other groups have the same perception of the core course lesson? 